4. Тараборин Р. С., Тараборина, Ю. В. Наполеон Бонапарт и составление Гражданского кодекса французов 1804 г / Р. С. Ю. В. Тараборин Тараборина // Социум и власть. - 2010. - № 1(25). - С. 73-76.

5. Тивоненко, Е. В. Гражданский кодекс Наполеона: его создание и значение / Е. В. Тивоненко // Событие и текст: встречи и размышления в библиотеке : сборник научных статей по материалам Республиканского научно-просветительского лектория. - Уфа : ЦКиР НБ Рб, 2017. - С. 150-154.

6. Шайжанова, А. Н. Влияние гражданского кодекса Наполеона на развитие цивилистики стран Европы / А. Н. Шайжанова // Аллея науки. - 2018. - Т. 1. - № 4(20). - С. 737-741.

\title{
Шутова М.А. \\ Историография вопроса воспитания подрастающего поколения в допетровской Руси
}

Кубанский государственньй университет

(Россия, Краснодар)

doi: 10.18411/trnio-10-2021-161

\section{Аннотация}

В данной статье был проведён обзор историографической базы по вопросам воспитания юношества в Российском государстве вплоть до XVIII столетия. Исследователями использовались вариативные подходы в изучение данного вопроса и был доступен разнообразный перечень источниковедческой базы, что во многом зависело от эпохи, в которой проживал учёный. Вопрос об воспитание отроков был и будет актуальным всегда, однако в разные исторические периоды востребованность в изучение данной тематики была не столь ординарная. Задача же современных исследователей - это изучение предшествующего опыта, опираясь на основные историографические достижения, источниковедческую базу с целью формирования новых воспитательных концепций.

Ключевые слова: историографический обзор, воспитание, образовательные концепции, наука, исторический опыт, образование.

\section{Abstract}

This article provides an overview of the historiographical base on the issues of youth education in the Russian state up to the XVIII century. The researchers used variable approaches to the study of this issue and a diverse list of source studies was available, which largely depended on the era in which the scientist lived. The question of the upbringing of adolescents has always been and will always be relevant, but in different historical periods, the demand for the study of this topic was not so ordinary. The task of modern researchers is to study the previous experience, relying on the main historiographical achievements, the source base in order to form new educational concepts.

Keywords: historiographic review, education, educational concepts, science, historical experience, education.

Детство важнейший период жизни каждого индивида. Именно данный временной промежуток жизни является одним из важных объектов исторических и социальноантропологических исследований. Взросление ребёнка в подавляющем большинстве случаев происходит в рамках семейного уклада. Как показывает исторический опыт, именно институт семьи, семейные ценности, а так же взаимоотношения детей и родителей во многом определяет социальное и культурное развитие общества в любой исторический период.

Актуальность темы обусловлена повышенным вниманием к роли ребёнка в обществе и о том, как она менялась по иерархической лестнице на протяжении истории.

В современной России проблема воспитания подрастающего поколения особенно ярко прослеживается, так как общество заинтересовано в формировании духовнонравственных и патриотических ценностей у молодёжи. Именно поэтому так необходимо изучение опыта прошлого, как для формирования полного представления общего уклада истории Российской, так и для заимствования воспитательных концепций и семейных порядков в современную жизнедеятельность. В условиях современных реалий и новшеств 
проблема воспитания детей с учётом исторического прошла выдвигается на первостепенные позиции.

Необходимо так же заметить, что актуальность работы обусловлена и небольшой историографической базой по данной тематике, что является одним из предметов нашего изучения. Проблемы детства и взаимоотношения родителей и детей рассматриваются исследователями, однако, как правило, внимание уделяется периодам с XVII века, а в свою очередь периоды, предшествующие во многом остаются без внимания. Тем не менее, важность проблемы изучения детства до XVII века представляет исследователю не легкую задачу реконструкции событий с помощью очень узкого и немногочисленного круга источниковедческих данных и историографической базы.

Объектом исследования являются историографические данные по проблематике изучения феномена детства в Московской Руси.

Предмет исследования: становление и развитие историографических концепции.

В отечественной историографии, посвященной вопросам семьи, воспитанию подрастающего поколения можно выделить несколько этапов. Первым этапом станет период с XIX века до 1917 года (дореволюционный). Характерными чертами этого периода является сочетание двух научных школ: историко-правовой и исторической. Вторым этапом стал период с 1917 года до начала 90-ых годов XX столетия (советский этап). На данном этапе, по причине доминирования идеологических установок, в основном изучались вопросы социально- экономических изменений в Московском обществе. Третий же этап (современный) характеризуется плюрализмом методологий в изучении межличностных, образовательных отношений в московской семье.

Одним из первых, кто обратился к проблеме семейный отношений в рамках нашего государства, был Николай Михайлович Карамзин, рассмотревший отношения внутри семьи в языческий период. Исследователь, неоднократно опираясь на повествование Нестора ссылается к выводу о дикости и жестокости между родителями и детьми. По его сведениям, о воспитании в дохристианской Руси не могло быть и речи, так как нередко упоминается факт убиения нежеланных новорожденных дочерей и о убийствах престарелых родителей своими же детьми. Последующие периоды не стали изучаться историком по данной тематики.

В первой половине XIX века исследованием семейных отношений занимались исследователи историко - правовой школы, такие как И.Ф. Эверс и А.М. Рейц. Так же в данный период большой вклад в изучение проблемы внесли К.А. Неволин и В.И. Сергеевич. Представители историко - правовой школы действительно одни из первых обратились к исследованию семейных отношений на Руси (не считая Николая Михайловича Карамзина). Однако для нашего исследования их труды обладали большим количеством недостатков, так как в основном они рассматривали институт семьи и отношения родителей и детей исключительно через призму юриспруденции и это неудивительно, так как их основной источниковедческой базой являлись правовые документы. Исследования историко-правовой школы в основном проводились без учёта социально-экономических процессов, происходивших в обществе и морально нравственных аспектов семейного уклада.

Неволин, в своём изучении определил, что на воспитательные традиции на Руси прямо повлияли нормы канонического и гражданского права Византии. Однако при этом он замечает, что многие греческие традиции нередко обходились. Как пример, это роль родителя в воспитании ребёнка. Если по греческому образцу доминирующая роль в воспитании ребёнка отводилась отцу, то по славянским традициям роли между родителями были распределены на двоих.

В середине XIX века древнерусская семья стала объектом изучения историков, одним из которых был Д.Н. Дубакин. В своей работе: «Влияние христианства на семейный быт русского общества в период до времени появления «Домостроя», он, опираясь на большое количество разноплановых источников, создал яркую картинку повседневного семейного быта на Руси. Ссылаясь на источник XVI столетия под руководством Сильвестра, он делает 
вывод о жестоких правилах воспитания подрастающего поколения, с применением физической силы. По мнению исследователя, данная мера оправдана тяжелыми условиями жизни ребёнка в средневековом обществе, что помогало им быть более дисциплинированными и строгими.

О языческих браках и о положении женщины - матери большой вклад внесли работы историков - исследователей А.В. Добрякова (именно он в своей работе «Русская женщина в домонгольского периода» отошёл от идеи рабского положения женщины на Руси и признал за ней широкий круг личных прав и свобод), С.С. Шашкова, В.О. Шульгина, К.Д. Кавелина, Н.С. Державина. Одним из главных плюсов исторической школы является выход за узкие границы права и концентрирование внимания на людях и отношениях между ними.

После 1917 года, как уже было нами замечено, изучение семьи и тем более такой узкой проблемы как детства отошло на второй план из-за господства марксистско-ленинской идеологии, предметами изучения которой были больше политические и экономические процессы, нежели социальные. Однако всё же имелось несколько достойных работ рассматривающий семейный уклад на Руси, это были исследования С.В. Юшкова, а также работа Б.А. Романова «Люди и нравы Древней Руси», которая была во многом посвящена воспитанию подрастающего поколения в рамках семьи.

Огромнейший вклад в изучении проблем детства и материнства на базе материалов по отечественной истории внесла исследовательница Наталья Львовна Пушкарёва в своих работах: «Мать и материнство на Руси X -XVII вв.», «Женщины Древней Руси», она освятила многие вопросы, связанные с материнским воспитанием ребёнка и особое внимание уделяла вопросу воспитания девочек на Руси. Именно Н.Л. Пушкарёва воссоздала многогранный образ древнерусской женщины: девушки, матери, хозяйки. Так же вопросами о роли древнерусской женщины в воспитании потомства писали исследователи Г.М. Данилов, О.М. Рапов, П.В. Снесаревский и другие. О положении детей на Руси писали такие историки как М.Ю. Брайчевский и Г. Прошин.

В современной исторической науке появилось ряд как правовых, так и социальных исследований семьи и детства. О правовом регулировании брачно-семейных отношений актуальной для нашего исследования оказалась работа В.В. Момотова: «Формирование семьи и брака в русском средневековом праве IX- XIV вв.». В своей работе он рассматривает проблемы заключения и расторжения браков, а также отношения, как между супругами, так и родителей, и детей.

Большую роль и помощь в нашем исследовании сыграли монографии российских историков, которые посвятили свои работы вопросам детства и воспитания на Руси. Среди таких работ, хотелось бы выделить работу В.В. Долгова, в своей работе: «Рождение и ранний период жизни ребёнка в Древней Руси...» он освятил основные вопросы об уходе за детьми, об обрядовой «защите» новорожденных, а также о формировании у подрастающего поколения ценностных ориентиров. Так же хотелось отметить работу О.Л. Янушкявичене: «Духовное воспитание в Древней Руси», в которой исследовательница уделила большое внимания образам древнерусской литературы, на которых воспитывались дети.

Не менее ценным историографическим материалом оказались работы С.А. Ганина «Феномен детства в Древней и Средневековой Руси», а также работа О.В. Арапова «Общая характеристика процесса воспитания детей на Руси», в которых авторы рассматривают положение ребёнка внутри семьи, периоды его взросления, круг обязанностей, а так же процесс обучения.

По вопросам о воспитании детей в княжеской и царской семье пригодились работа Людмилы Алексеевны Чёрной: «Повседневная жизнь московских государей» и автореферат Марины Гарриевны Ракитиной «Воспитание царских детей...», с помощью данных работ становится возможным воссоздать основные воспитательные концепции княжеских и царских наследников.

Не смотря на определённый шаг в современной России в изучении семейных отношений и положения ребёнка на Руси, как уже было подмечено, в основном внимание 
исследователей привлекают временные рамки с XVII - XX век. Вследствие чего мы можем говорить об не исчерпанности темы, так как широких обобщающих исследований по нашей тематике, написанных с использованием последних достижений исторической науки, всё же ещё не появилось. Но в то же время, с помощью привлечения как можно большего количества источников и с помощью определённых разработок исследователей по определённым вопросам, мы можем вывести исследования на новый уровень путём обобщения имеющегося материала.

$$
* * *
$$

1. Карамзин Н. М. История государства Российского. М, 1989. Т. 1 ; 1991. Т. 1-3. 456 с.

2. Эверс И. Ф. Г. Древнейшее русское право в историческом его раскрытии. СПб., 1835. 234 с.

3. Неволин К. А. Полное собрание сочинений. СПб., 1857. Т. 3 : История российских и гражданских законов, ч. $1.212 \mathrm{c}$.

4. Добряков А. Русская женщина в домонгольский период. СПб., 1864. 343 с.

5. Романов Б. А. Люди и нравы древней Руси. Историко-бытовые очерки. М.; Л., 1966. 567 с.

6. Момотов В. В. Формирование русского средневекового права в IX - XIV вв. М., 2003.123 с. 